\title{
Nutritional Value of Lemnaceae Macrophytes
}

\author{
D.A. Mirzaeva ${ }^{1}$, K.S. Maksumkhodjaeva ${ }^{1}$, N.A. Khujamshukurov ${ }^{1}$, Sh.Q. Gazieva ${ }^{1}$, \\ X.O. Abdullaev ${ }^{1}$, Sh.X. Iskhakova ${ }^{1}$ and D.Kh. Kuchkarova ${ }^{2} *$ \\ ${ }^{1}$ Tashkent Chemical-Technological Institute, ${ }^{2}$ Tashkent Architectural-Civil Engineering \\ Institute, Uzbekistan \\ *Corresponding author
}

\begin{tabular}{l} 
Ke y w o r d s \\
Lemnaceae, Lemna, \\
Lemna minor, \\
Lemna gibba, Feed, \\
Fish feed, Protein, \\
Amino acid \\
\hline Article Info \\
Accepted: \\
28 March 2020 \\
Available Online: \\
10 April 2020
\end{tabular}

In this article, the separation of dry mass from the wet biomass of Lemna minor and Lemna gibba, the dry mass and the preservation of protein and the amount of amino acids in it were investigated. In particular, it was determined that Lemna minor forms an average of $5.21 \%$ dry weight, Lemna gibba an average of $6.03 \%$. It was noted that grown $1 \mathrm{~m}^{2}$ of Lemna minor forms an average of $1,429.83 \mathrm{~g}, 274.53 \mathrm{~g}$ is obtained from it, Lemna gibba forms an average of $1628.00 \mathrm{~g}, 268.91 \mathrm{~g}$ is obtained from it. Having examined the composition of the dry mass, it was noted that, Lemna minor synthesizes $-16.10 \%$, Lemna gibba synthesizes $15.02 \%$ of the protein. Essential amino acids in the purified duckweed protein have been investigated. Here, in the composition of purified proteins obtained from Lemna minor, threonine is 5.03; valine - 7.59; methionine - 0.39; isoleucine -5.83 ; leucine - 10.16; tyrosine - 2.73; phenylalanine 6.21 and lysine $6.13 \mathrm{mg} / 100 \mathrm{mg}$, in the composition of purified proteins obtained from Lemna gibba threonine 4.75; valine - 7.36; methionine 1.23; isoleucine -5.74 ; leucine - 10.61; tyrosine - 4.32; phenylalanine 6.60 and lysine 6.13 $\mathrm{mg} / 100 \mathrm{mg}$. Therefore, to determine the true nutritional value, it is necessary to isolate pure protein from the dry mass and to study the composition of the amino acid in the protein.

\section{Introduction}

Macrophytes belonging to the Lemnaceae family stand out for their importance in various industries. Including, in the production of food products it is an effective resource used for the treatment of wastewater and chemically damaged waters from heavy metals and pesticides (Mkandawire et al., 2007; Radić et al., 2011, 2014). Based on macrophytes belonging to the Lemnaceae family, industrial production was widely established, one of the main is duckweed flour, ingredients rich in fatty acids, various feed additives for poultry, protein feed for fish (Haustein et al., 1994; Bairagi et al., 2002). It is noted that flour made on the basis of macrophytes of the genus Lemna contains $35-45 \%$ of crude protein and $7-10 \%$ of fiber (Olorunfemi et al., 2006; Hasan and Chakrabarti, 2009; Rojas et al., 2014). Parabel Inc. (Melbourne, FL) introduced the production of LPC (Lemna Protein Concentrate) based on a new technology for 
the extraction of crude protein and essential amino acids based on Lemna species, which is characterized by the retention of about $68 \%$ of crude protein in LPC (Rojas et al., 2014).

Annual production figures based on Lemnaspp are also reflected in scientific sources. In particular, production capacity was noted, 60-145 t/ha/year in ThailandVietnam (Landolt and Kandeler, 1987), 36-51 t/ha/year in Israel (Leng at al., 1995), 7-8 t/ha/year in Russia (FAO, 2001), 7-15 t/ha/year in Uzbekistan (FAO, 2001), 22-34 t/ha/year in Germany (Mkandawire and Dudel, 2005), 30-70 t/ha/year in India (Leng at al., 1995), 30 t/ha/year in Egypt (Landolt and Kandeler, 1987) and 57-185 t/ha/year in various regions of the USA (FAO, 2001).

Now it is clear that these numbers have increased several hundred times. In particular, the weather in Uzbekistan is favorable, the number of sunny days is almost 308 days, it is possible to continue the growth of macrophytes from March to November (Khujamshukurov et al., 2016). Thus, on the basis of our scientific studies, it was proved that in the conditions of Uzbekistan it is possible to obtain $154 \mathrm{t} / \mathrm{ha} /$ year of wet biomass or 27.34 tons of dry weight. It is known that from the composition of any object, that is, the indicator of obtaining dry biomass from wet biomass is very important in the production environment (Khujamshukurov, 2011). From various scientific sources, dry mass formation in Lemna-based products varies from $3.5 \%$ (Landesman, 2000), 4.9\% (Goopy et al., 2003), 5.1\% (Rusoff et al., 1980; (FAO, 2001).

This leads to the appearance of various indicators of the amount of protein in the products based on the calculation of obtaining dry mass from wet biomass.
Therefore, in this work, macrophytes of the Lemnaceae family were identified as Lemna minor and Lemna gibba for the formation of wet biomass, yield of dry mass, protein formation, and analysis of amino acid composition.

\section{Materials and Methods}

Objects of study: types of microphytes Lemna minor and Lemna gibba were used, isolated from different regions of Uzbekistan, and stored, grown in the scientific laboratory "Biotechnology" of the Tashkent Institute of Chemical Technology. Growing conditions: water temperature $20^{\circ} \mathrm{C}$. The duration of cultivation of all samples was 7 days. Culture medium is a standard organic medium. Method R. Scoups (1985) was used in protein purification. During protein separation, the dry mass of duckweed was crushed and neutralized with hexane. $1.5 \mathrm{~g}$ of flour from both types of duckweed was obtained and sequentially extracted in $5 \mathrm{ml}$ of water, $5 \mathrm{ml}$ of $5 \mathrm{M}$ sodium chloride, $5 \mathrm{ml}$ of absolute methanol and $5 \mathrm{ml}$ of $0.2 \mathrm{M}$ phosphate buffer (pH-8.0). Each extraction was carried out for 20 minutes. After extraction, the solutions were centrifuged for $15 \mathrm{~min}$ at a speed of $8000 \mathrm{rpm}$. The amount of protein in the supernatant was determined by the Lowry method.

A calibration graph was constructed using a standard sample (albumin) to determine the amount of protein using the Lowry method.

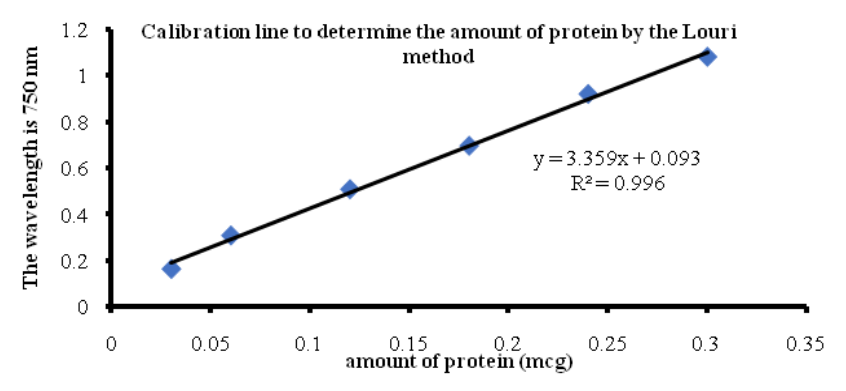


For amino acid analysis, $5 \mathrm{mg}$ of sterile duckweed flour (protein) was hydrolyzed in 5 $\mathrm{ml}$ of $5.7 \mathrm{~N} \mathrm{HCl}$ at $110^{\circ} \mathrm{C}$ in an airless environment for 24 hours. The hydrolysate was evaporated, the dry residue was dissolved in water triethylamine-acetonitrile, mixed in a ratio of 1:7:1, and dried. This process was performed twice to neutralize acids. In the reaction with phenylthioisocyanite, the free amino acid phenylthio-carbamyl (FTK) was obtained by the method of A. Steve and Cohen Daviel (1988). Qualitative and quantitative calculations were performed by comparing the concentration of the studied amino acids, determining the free amino acid FTK and preserving the standard peak area and length of time.

The calculation of the statistical error, mean value, confidence intervals and standard deviations from experimental data was carried out using the STATISTICA 6.0 computer program and standard methods. The statistical significance of the results was determined using Student's t-test.

\section{Results and Discussion}

According to the results, it was noted that the yield of dry mass from the moist biomass of Lemna minor and Lemna gibba are different (Figure 1-2). In particular, while Lemna minor forms an average dry mass of $5.21 \%$, it was found that Lemna gibba forms an average of $6.03 \%$. Lemna minor, grown on an area of $1 \mathrm{~m} 2$, averaged $1,429.83 \mathrm{~g}$, of which the dry matter yield was $274.53 \mathrm{~g}$, in Lemna gibba this indicator averaged 1,628.00 g, of which the dry weight yield was $268.91 \mathrm{~g}$.

When determining the amount of protein in this dry mass, it was noted that the average preservation of Lemna minor protein was $16.10 \%$ of protein synthesis (Fig. 3), while Lemna gibba averaged $15.02 \%$ of protein synthesis (Fig. 4). In scientific sources, studies based on Lemna, it was noted that the average conservation of protein is $16-40 \%$.

This can be explained by the fact that these species are grown in a nutrient medium specifically for protein synthesis and by controlling the amount of nitrogen, phosphorus and potassium in it. How much protein is stored by duckweed, its amino acid content determines the prospects for its use (Maciejewska-Potapczykowa, 1970).

Therefore, in subsequent studies, the dried biomass of duckweed and the amino acids of the proteins isolated from it were analyzed. Table 1 presents the analysis of the amino acid composition of Lemna minor. It was also noted that the content of all amino acids, such as threonine, serine, alanine, is high in pure protein. Therefore, the production of pharmaceuticals and dietary supplements based on duckweed is important.

Table 2 shows the analysis of dry weight and amino acid content in the purified protein Lemna gibba. According to the results obtained, when analyzing the amino acid content in the dry weight of Lemna gibba (mg $/ 100 \mathrm{mg}$ ), it is seen that the proportion of dry weight of amino acids is $16.71 \%$.

It was noted that the amount of essential amino acids in dry weight was $6.76 \%$ of the total number of amino acids, while the amount of essential amino acids in purified protein was $46.74 \%$.

As a result of the analysis, it was noted that the percentage of amino acids in the dry weight of Lemna minor averaged $22.73 \%$. In this study, an analysis of dry weight and purified protein content of Lemna minor revealed an average of $10.13 \%$ of the total number of amino acids and an average of $44.06 \%$ of the essential amino acids in pure protein (Fig. 5). 
As a result of the analysis, it was noted that the percentage of amino acids in the dry weight of Lemnagibba averaged $16.71 \%$. During the study, an analysis of the dry weight and the content of purified protein in Lemna gibba revealed an average of $6.95 \%$ of the total number of amino acids and an average of $46.746 \%$ of the essential amino acids in pure protein (Fig. 6). When these parameters were studied in the dry biomass of Lemna minor, the difference between the amino acids Threonine (1.65), Valine (1.74), Methionine (0.09), Izoleucine (1.34), Leucine (2.33), Tyrosine was observed (0.63), Phenylalanine (1.43) and Lysine (1.40). Thus, the essential amino acids in Lemna Minor retain more leucine (0.89), phenylalanine $(0.48)$ and lysine $(0.35)$ and differ in that the proportion of essential amino acids in the total number of amino acids is $10.13 \%$.

Subsequent studies analyzed the amount of essential amino acids in the purified protein obtained from duckweed. In particular, when the dry biomass of Lemna minor was studied, the amount of threonine was 5.03; valine 7.59; methionine - 0.39; isoleucine -5.83; leucine - 10.16; tyrosine - 2.73; phenylalanine $6.21 \mathrm{mg}$ and lysine $6.13 \mathrm{mg} / 100 \mathrm{mg}$ (Fig. 7).

Picture.1 The output of dry weight from wet weight Lemna minor, g / 100g

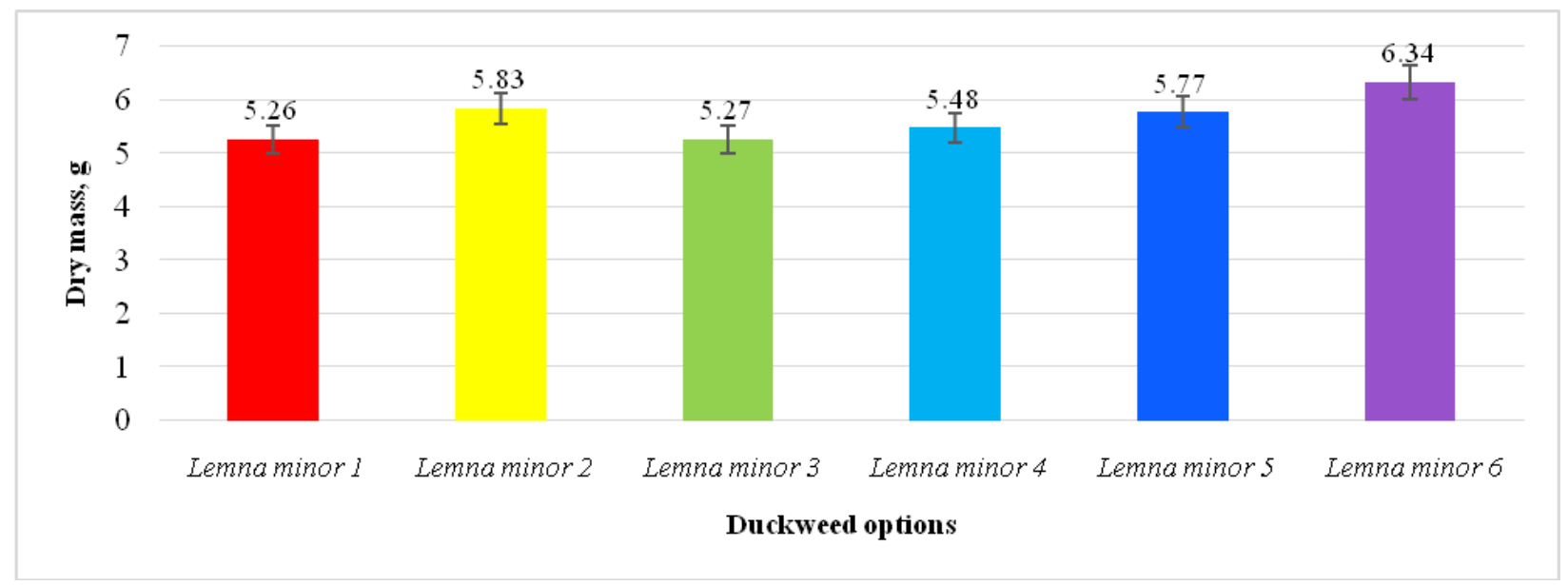

Figure.2 The output of dry weight from wet weight Lemna gibba, g / 100g

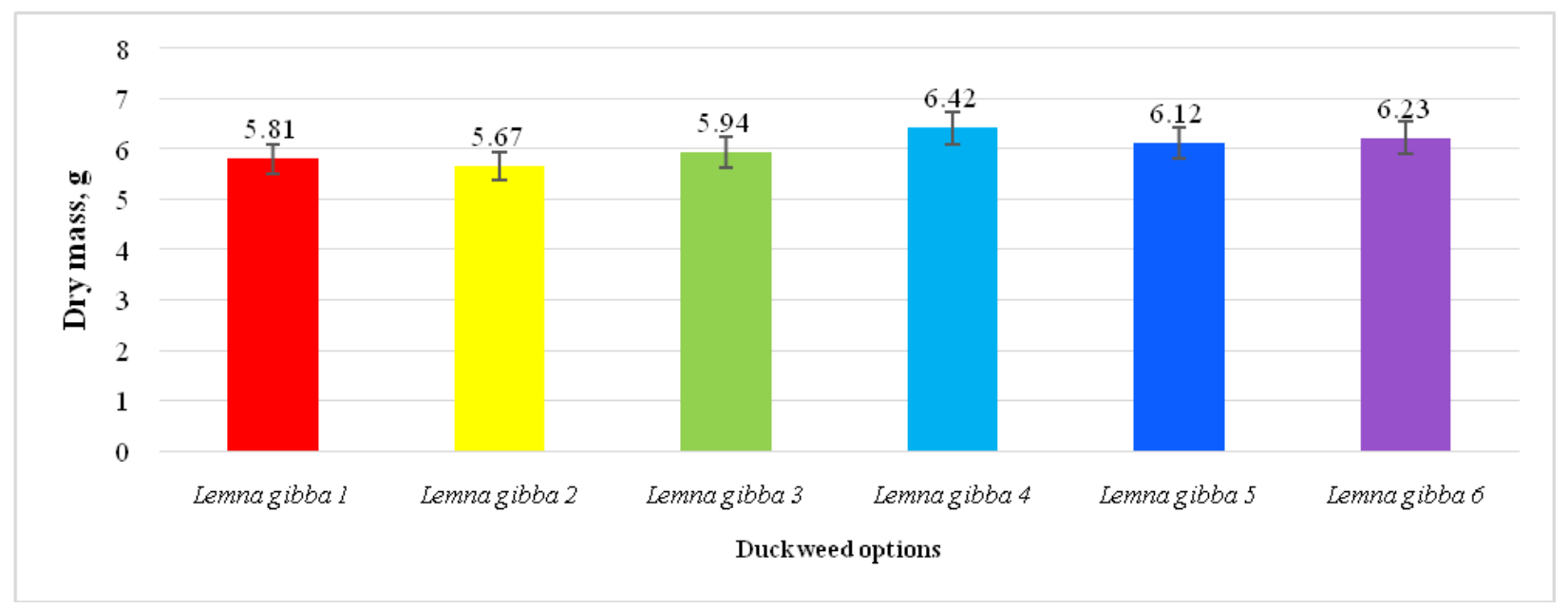


Figure.3 Protein storage in Lemna minor

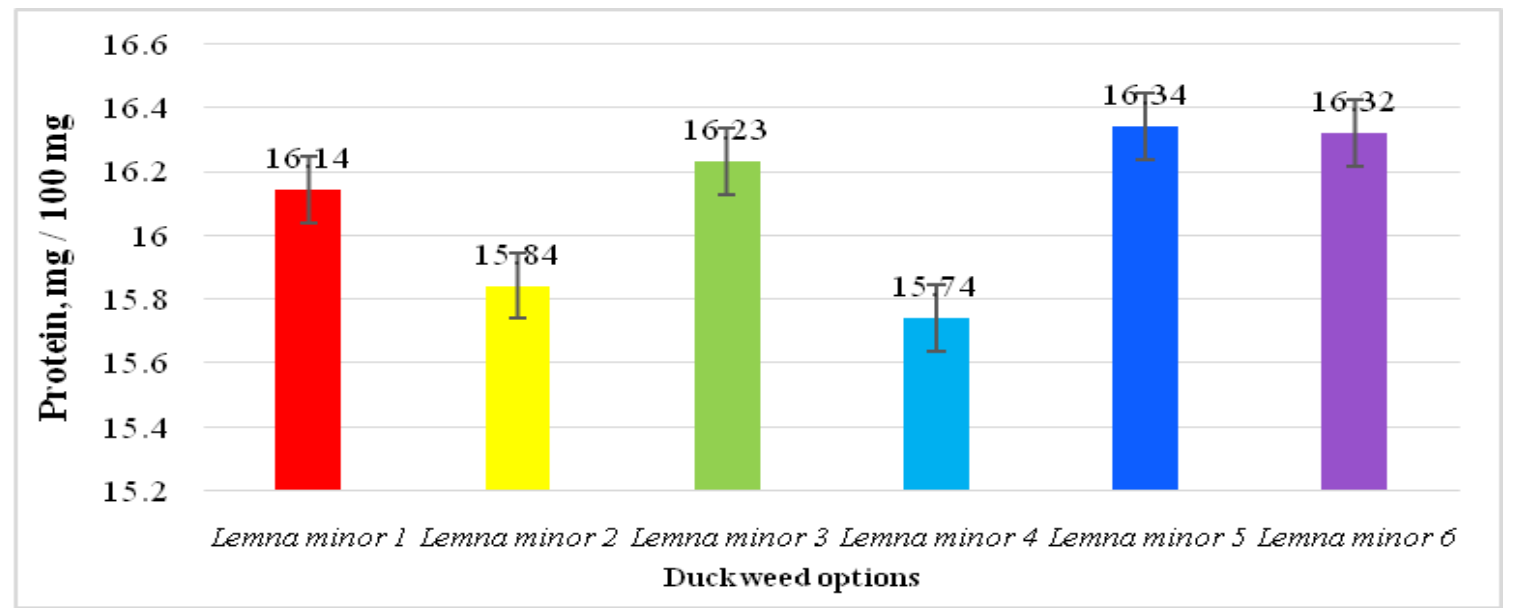

Figure.4 Saving protein in Lemna gibba

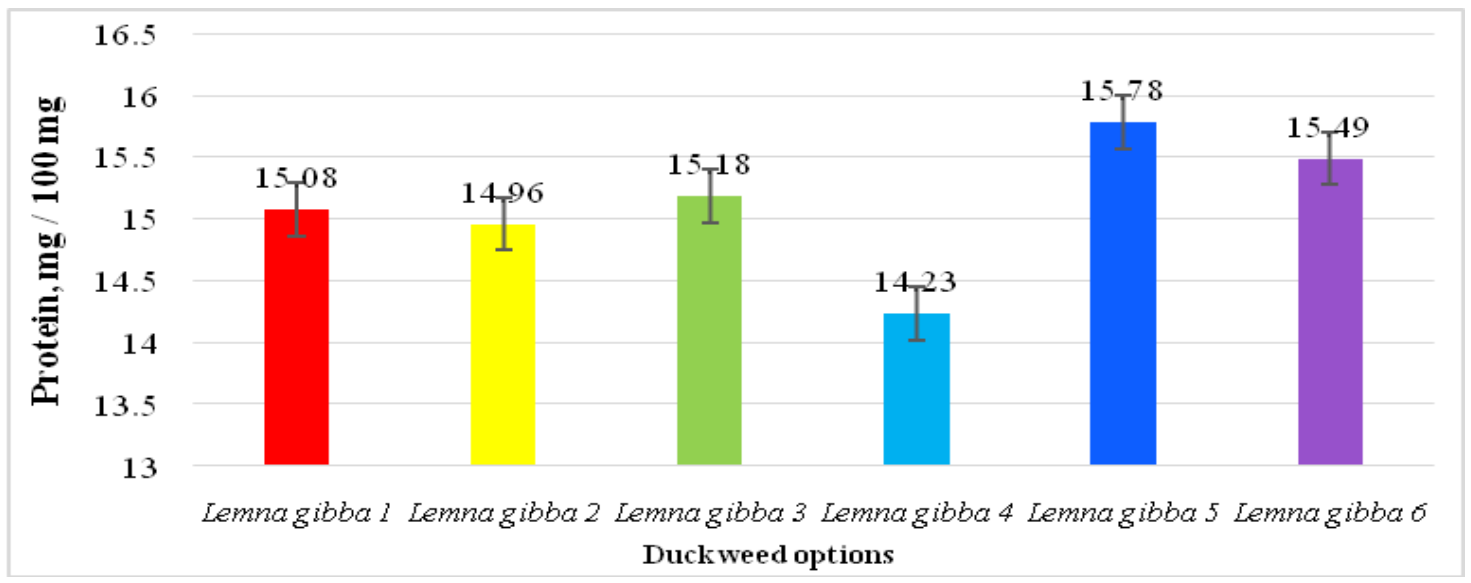

Figure.5 The amount of essential amino acids in the dry mass of duckweed, mg/100 mg

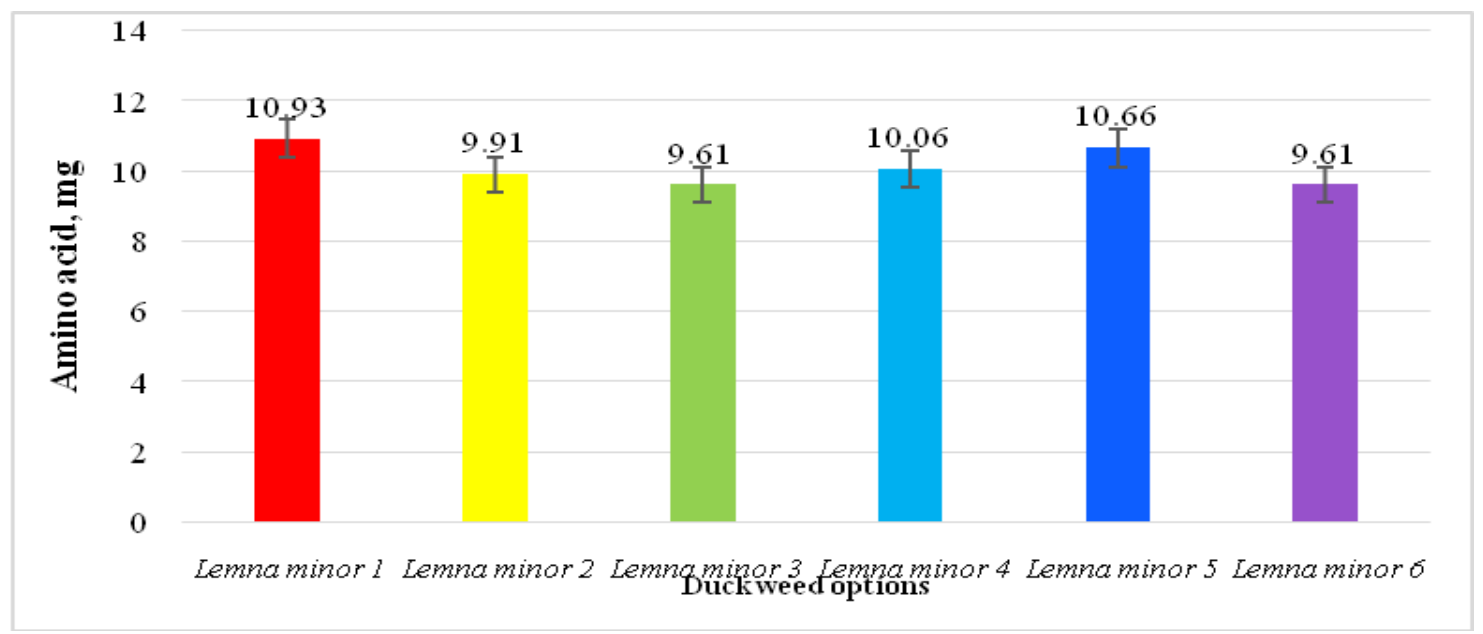


Figure.6 The amount of essential amino acids in the dry mass of duckweed, mg / $100 \mathrm{mg}$

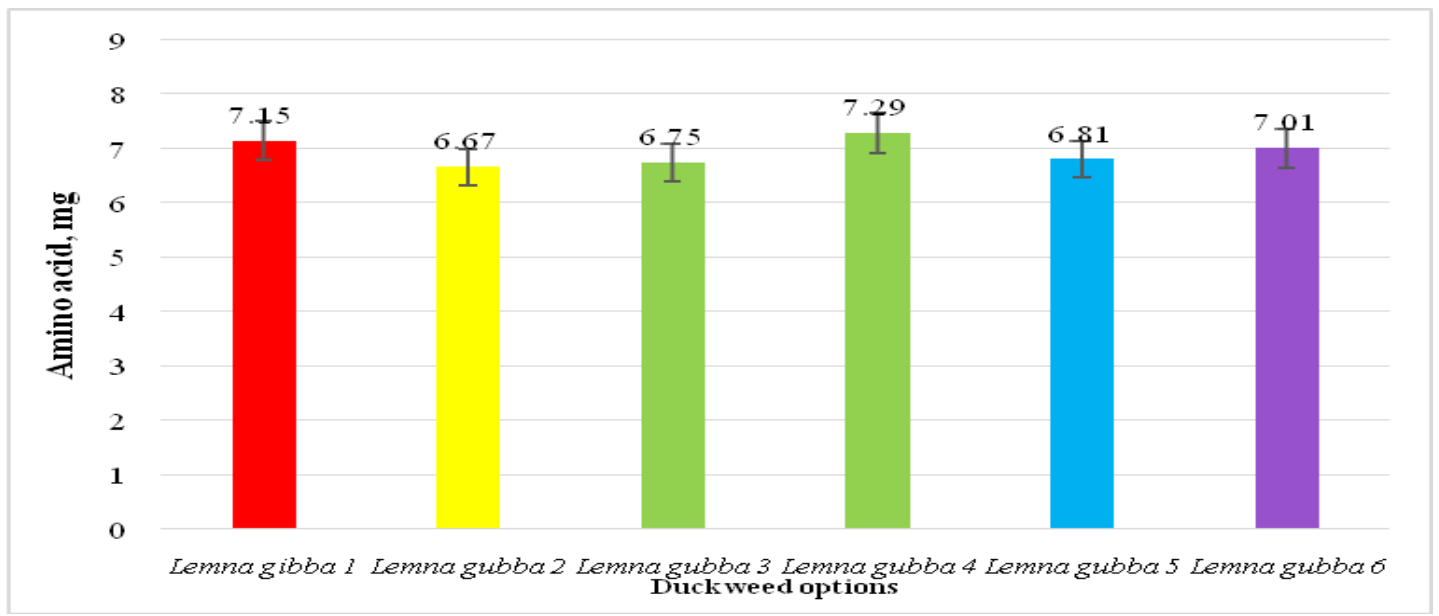

Figure.7 Amount of essential amino acids in duckweed protein, mg / $100 \mathrm{mg}$

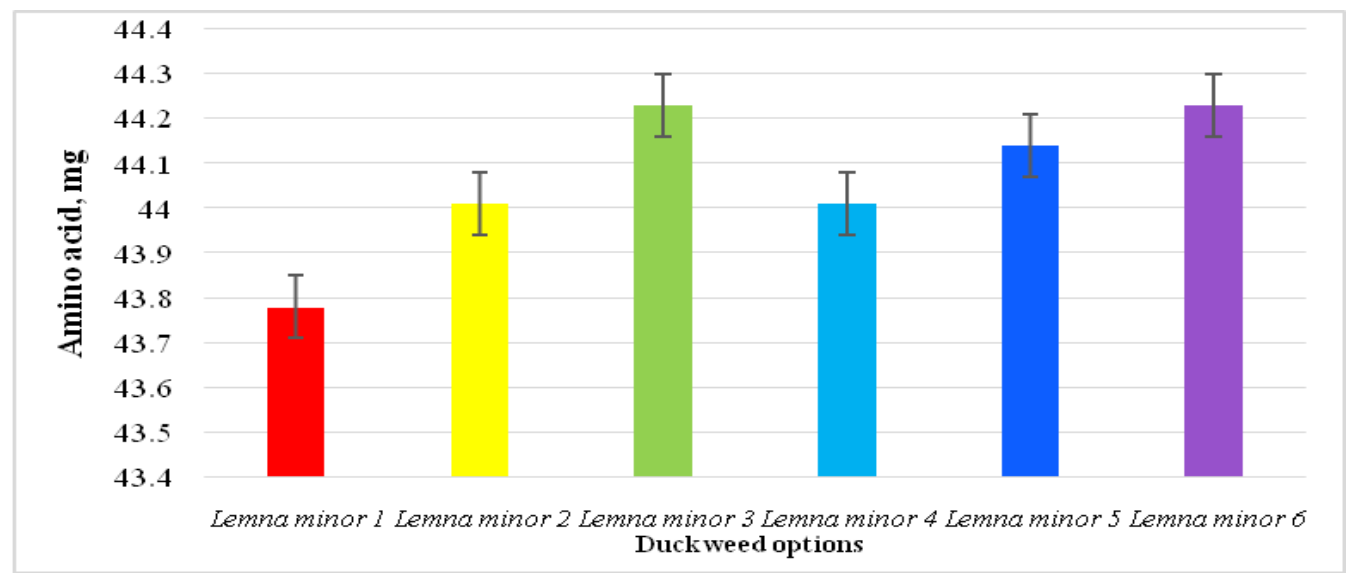

Figure.8 The amount of essential amino acids in duckweed protein, mg / $100 \mathrm{mg}$

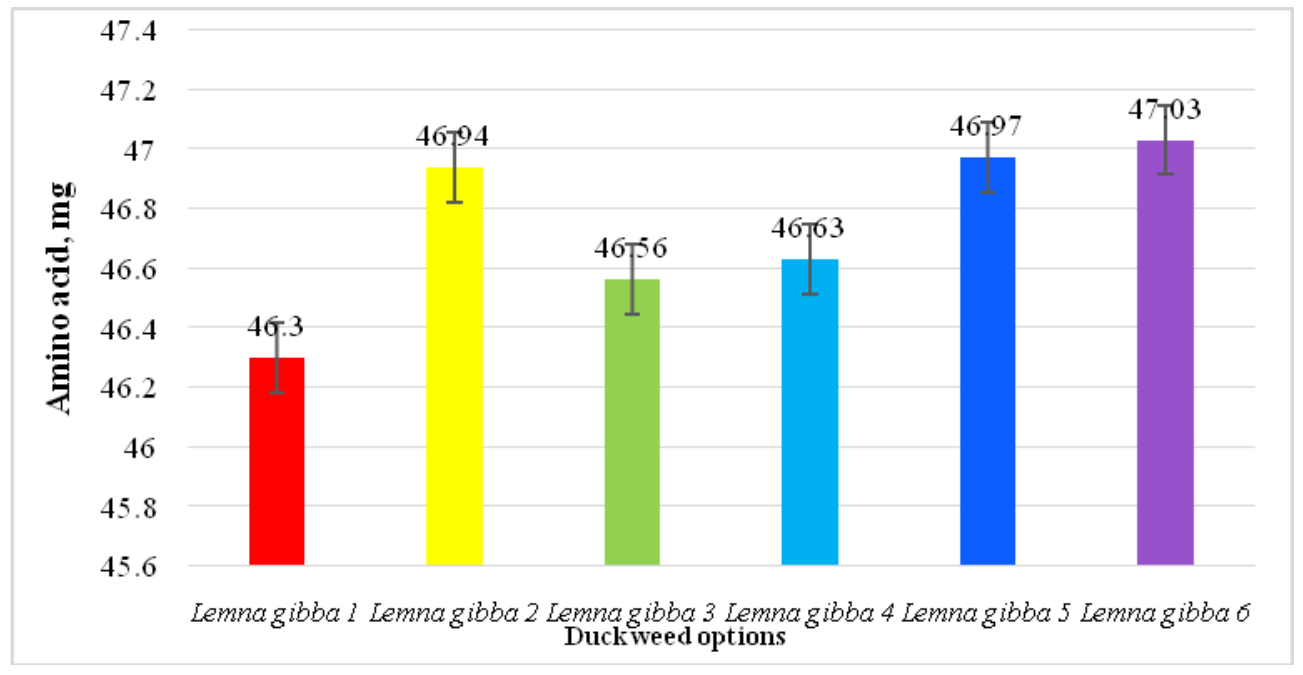


Table.1 Analysis of the amino acid composition of Lemna minor, mg / $100 \mathrm{mg}$

\begin{tabular}{|c|c|c|c|c|c|c|c|c|c|c|c|c|c|c|}
\hline \multirow[t]{3}{*}{ Nameofaminoacid } & \multicolumn{12}{|c|}{ Experimental options, $\mathrm{mg} / 100 \mathrm{mg}$ in biomass } & \multirow{2}{*}{\multicolumn{2}{|c|}{ Middle }} \\
\hline & \multicolumn{2}{|c|}{1} & \multicolumn{2}{|c|}{2} & \multicolumn{2}{|c|}{3} & \multicolumn{2}{|c|}{4} & \multicolumn{2}{|c|}{5} & \multicolumn{2}{|c|}{6} & & \\
\hline & $\mathbf{A}$ & $\mathbf{5}$ & $\mathbf{A}$ & $\mathbf{5}$ & $\mathbf{A}$ & $\mathbf{5}$ & $\mathbf{A}$ & $\mathbf{5}$ & $\mathbf{A}$ & $\mathbf{5}$ & $\mathbf{A}$ & $\mathbf{5}$ & drymass & protein \\
\hline Asparticacid & 2,43 & 9,72 & 2,20 & 9,77 & 2,14 & 9,82 & 2,24 & 9,77 & 2,37 & 9,80 & 2,14 & 9,82 & 2,25 & 9,78 \\
\hline Threonine & 1,25 & 4,99 & 1,14 & 5,02 & 1,10 & 5,04 & 1,15 & 5,02 & 1,22 & 5,03 & 1,10 & 5,04 & 1,16 & 5,03 \\
\hline Serine & 0,99 & 3,98 & 0,90 & 4,00 & 0,87 & 4,02 & 0,91 & 4,00 & 0,97 & 4,01 & 0,87 & 4,02 & 0,92 & 4,01 \\
\hline Proline & 1,19 & 4,80 & 1,08 & 4,82 & 1,05 & 4,85 & 1,10 & 4,82 & 1,16 & 4,84 & 1,05 & 4,85 & 1,11 & 4,83 \\
\hline Glutamicacid & 3,32 & 13,30 & 3,01 & 13,37 & 2,92 & 13,44 & 3,05 & 13,37 & 3,24 & 13,41 & 2,92 & 13,44 & 3,08 & 13,39 \\
\hline Glycine & 1,81 & 7,23 & 1,64 & 7,27 & 1,59 & 7,31 & 1,66 & 7,27 & 1,76 & 7,29 & 1,59 & 7,31 & 1,67 & 7,28 \\
\hline Alanine & 1,94 & 7,75 & 1,76 & 7,79 & 1,70 & 7,82 & 1,78 & 7,79 & 1,89 & 7,81 & 1,70 & 7,82 & 1,79 & 7,80 \\
\hline Cystine* & - & - & - & - & - & - & - & - & - & - & - & - & - & - \\
\hline Valine & 1,88 & 7,54 & 1,70 & 7,58 & 1,65 & 7,62 & 1,73 & 7,58 & 1,83 & 7,60 & 1,65 & 7,62 & 1,74 & 7,59 \\
\hline Methionine & 0,10 & 0,38 & 0,09 & 0,39 & 0,09 & 0,39 & 0,09 & 0,39 & 0,10 & 0,39 & 0,09 & 0,39 & 0,09 & 0,39 \\
\hline Izoleucine & 1,44 & 5,79 & 1,31 & 5,82 & 1,27 & 5,85 & 1,33 & 5,82 & 1,41 & 5,84 & 1,27 & 5,85 & 1,34 & 5,83 \\
\hline Leucine & 2,52 & 10,10 & 2,28 & 10,15 & 2,21 & 10,20 & 2,32 & 10,15 & 2,46 & 10,18 & 2,21 & 10,20 & 2,33 & 10,16 \\
\hline Tyrosine & 0,68 & 2,71 & 0,62 & 2,73 & 0,60 & 2,74 & 0,63 & 2,73 & 0,67 & 2,74 & 0,60 & 2,74 & 0,63 & 2,73 \\
\hline Phenylalanine & 1,54 & 6,17 & 1,40 & 6,20 & 1,36 & 6,24 & 1,42 & 6,20 & 1,51 & 6,22 & 1,36 & 6,24 & 1,43 & 6,21 \\
\hline Lysine & 1,51 & 6,09 & 1,37 & 6,13 & 1,33 & 6,16 & 1,39 & 6,13 & 1,48 & 6,14 & 1,33 & 6,16 & 1,40 & 6,13 \\
\hline Histidine & 0,57 & 2,28 & 0,51 & 2,29 & 0,50 & 2,30 & 0,52 & 2,29 & 0,55 & 2,30 & 0,50 & 2,30 & 0,53 & 2,30 \\
\hline Arginine & 1,15 & 4,59 & 1,04 & 4,61 & 1,01 & 4,64 & 1,06 & 4,61 & 1,12 & 4,63 & 1,01 & 4,64 & 1,07 & 4,62 \\
\hline Tryptophan** & 0,20 & 0,84 & 0,18 & 0,84 & 0,18 & 0,84 & 0,19 & 0,84 & 0,20 & 0,84 & 0,18 & 0,84 & 0,19 & 0,84 \\
\hline
\end{tabular}


Table.2 Analysis of the amino acid composition of Lemna gibba, mg / $100 \mathrm{mg}$

\begin{tabular}{|c|c|c|c|c|c|c|c|c|c|c|c|c|c|c|}
\hline \multirow[t]{3}{*}{ Name of aminoacid } & \multicolumn{12}{|c|}{ Experimental options, mg/100 mg } & \multirow{2}{*}{\multicolumn{2}{|c|}{$\begin{array}{c}\text { The average amount of } \\
\text { amino acids }\end{array}$}} \\
\hline & \multicolumn{2}{|c|}{1} & \multicolumn{2}{|c|}{2} & \multicolumn{2}{|c|}{3} & \multirow{2}{*}{$\begin{array}{l}4 \\
\mathbf{A}\end{array}$} & \multirow[b]{2}{*}{ Б } & \multicolumn{2}{|c|}{5} & \multicolumn{2}{|c|}{6} & & \\
\hline & $\mathbf{A}$ & $\mathbf{5}$ & $\mathbf{A}$ & Б & $\mathbf{A}$ & $\mathbf{6}$ & & & A & Б & $\mathbf{A}$ & Б & drymass & protein \\
\hline Asparticacid & 1,87 & 10,47 & 1,74 & 10,61 & 1,76 & 10,52 & 1,90 & 10,54 & 1,78 & 10,62 & 1,83 & 10,63 & 1,82 & 10,56 \\
\hline Threonine & 1,08 & 4,70 & 1,01 & 4,77 & 1,02 & 4,73 & 1,10 & 4,74 & 1,03 & 4,77 & 1,06 & 4,78 & 1,05 & 4,75 \\
\hline Serine & 0,82 & 3,84 & 0,76 & 3,89 & 0,77 & 3,86 & 0,83 & 3,86 & 0,78 & 3,89 & 0,80 & 3,90 & $\mathbf{0 , 8 0}$ & 3,87 \\
\hline Proline & 0,98 & 4,31 & 0,91 & 4,37 & 0,92 & 4,33 & 1,00 & 4,34 & 0,93 & 4,37 & 0,96 & 4,37 & $\mathbf{0 , 9 5}$ & 4,35 \\
\hline Glutamicacid & 2,31 & 11,17 & 2,15 & 11,32 & 2,18 & 11,23 & 2,35 & 11,25 & 2,19 & 11,33 & 2,26 & 11,35 & 2,24 & 11,28 \\
\hline Alanine & 1,19 & 6,75 & 1,11 & 6,84 & 1,12 & 6,78 & 1,21 & 6,79 & 1,13 & 6,84 & 1,16 & 6,85 & 1,15 & 6,81 \\
\hline Cystine & - & - & - & - & - & - & - & - & - & - & - & - & - & - \\
\hline Valine & 0,92 & 7,29 & 0,86 & 7,39 & 0,87 & 7,33 & 0,94 & 7,34 & 0,88 & 7,40 & 0,91 & 7,41 & $\mathbf{0 , 9 0}$ & 7,36 \\
\hline Methionine & 0,12 & 1,22 & 0,11 & 1,24 & 0,11 & 1,23 & 0,12 & 1,23 & 0,11 & 1,24 & 0,11 & 1,24 & 0,11 & 1,23 \\
\hline Izoleucine & 1,09 & 5,69 & 1,02 & 5,77 & 1,03 & 5,72 & 1,11 & 5,73 & 1,04 & 5,77 & 1,07 & 5,78 & 1,06 & 5,74 \\
\hline Leucine & 1,48 & 10,51 & 1,38 & 10,65 & 1,40 & 10,57 & 1,51 & 10,58 & 1,41 & 10,66 & 1,45 & 10,67 & 1,44 & 10,61 \\
\hline Tyrosine & 0,40 & 4,28 & 0,37 & 4,34 & 0,38 & 4,30 & 0,41 & 4,31 & 0,38 & 4,34 & 0,39 & 4,34 & 0,39 & 4,32 \\
\hline Lysine & 1,08 & 6,07 & 1,01 & 6,15 & 1,02 & 6,10 & 1,10 & 6,11 & 1,03 & 6,16 & 1,06 & 6,17 & 1,05 & 6,13 \\
\hline Histidine & 0,40 & 2,78 & 0,37 & 2,82 & 0,38 & 2,79 & 0,41 & 2,80 & 0,38 & 2,82 & 0,39 & 2,82 & $\mathbf{0 , 3 9}$ & 2,80 \\
\hline Arginine & 0,99 & 6,31 & 0,92 & 6,39 & 0,93 & 6,34 & 1,01 & 6,35 & 0,94 & 6,40 & 0,97 & 6,40 & 0,96 & 6,36 \\
\hline Tryptophan* & 0,12 & 0,91 & 0,11 & 0,92 & 0,11 & 0,92 & 0,12 & 0,92 & 0,11 & 0,92 & 0,11 & 0,93 & 0,11 & 0,92 \\
\hline
\end{tabular}


These amino acids are visible in the example of proteins obtained in pure form from Lemna gibba, threonine is 4.75; valine - 7.36; methionine - 1.23; isoleucine -5.74; leucine 10.61 ; tyrosine - 4.32; phenylalanine was found to be 6.60 and the lysine level was 6.13 $\mathrm{mg} / 100 \mathrm{mg}$.

Subsequent studies determined the quantitative fractions of the amino acid content in the dry mass and in the composition of the purified protein (Fig. 7-8). According to the results, the Lemna minor protein in the variance of the variants, respectively, 43.78; 44.01; 44.23; 44.01; 44.14 and $44.23 \mathrm{mg} / 100 \mathrm{mg}$ were observed (Fig. 7).

It turned out that their share relative to the total number of amino acids was $44.06 \mathrm{mg}$. The proportion of essential amino acids in the protein obtained in pure form from Lemna gibba, the variance of the variants was respectively 46.30; 46.94, 46.56; 46.63, $46.97,47.23 \mathrm{mg} / 100 \mathrm{mg}$ and an average of $46.74 \mathrm{mg}$ was noted (Fig. 8). Analyzing the obtained results, it is important to determine the amino acid content in a pure protein in the production of a Lemna-based food product, and it is also important to determine the protein content in dry weight and its amino acid composition, and most importantly, the content of essential amino acids that are directly used in production.

As a result of the study, it was concluded that the nutritional value of duckweed can be incorrectly estimated due to the lack of access to accurate data due to losses in protein analysis in the dry mass of duckweed and amino acids. Therefore, in determining its true nutritional value, it is advisable to separate the pure protein from the dry mass and analyze the amino acid content in this protein. This will play an important role in the future production of pharmaceutical, food and food products based on duckweed.

\section{Acknowledgements}

This study was carried out as part of an innovative project of the Ministry of Innovative Development of the Republic of Uzbekistan No. I-OT-2019-21.We express our gratitude to the staff of the Institute of Bioorganic Chemistry named O. Sodikov of the Academy of Sciences of the Republic of Uzbekistan (Ph.D., associate professor IshimovU.J.), the scientific laboratory "Biotechnology" (prof. N.A. Khujamshukurov) of the Tashkent Institute of Chemical Technology.

\section{References}

Bairagi A., Sarkar-Ghosh K., Sen S.K., Ray A.K. 2002. Duckweed (Lemna polyrhiza) leaf meal as a source of feedstuff in formulated diets for rohu (Labeo rohita Ham.) fingerlings after fermentation with a fish intestinal bacterium. Bioresour. Technol. 85:1724.

FAO. 2001. Duckweed: A tiny aquatic plant with enormous potential for agriculture and environment. Food and Agricultural Organisation, Geneva. Pp.108.

Goopy J.P., Murray P.J. 2003. A Review on the Role of Duckweed in Nutrient Reclamation and as a Source of Animal Feed. Asian-Aust. J. Anim. Sci. Vol 16. No.2:297-305.

Hasan, M. R., and R. Chakrabarti. 2009. Floating aquatic macrophytes Duckweeds. In: M. R. Hasan and R. Chakrabarti, editors, Use of algae and aquatic macrophytes as feed in smallscale aquaculture. Food and Agric. Organ. of the U. N., Rome. p. 29-52.

Haustein A.T., Gilman A.K., Skillicorn 
P.W.1994. Performance of broiler chickens fed diets containing duckweed (Lemna gibba). J. Agric. Sci. 122:285-289.

Khujamshukurov N.A. 2011. Alternative protein products. J. XXI-technology. 4(5): 14-15.

Khujamshukurov N.A., Nurmuxamedova V.Z. 2016. Production feed: modern trend and development aspect. Scientific overview. J. Zooveterinary. №8 (105): 34-37.

Landesman L. 2000. Effects of Herbivory and Competition on Growth of Lemnaceae in Systems for Wastewater Treatment and Livestock Feed Production, University of Louisiana at Lafayette, Louisiana. Pp.150.

Landolt E., Kandeler E. 1987. The Family Lemnaceae: A monographic study (vol.2) Phytochemistry, Physiology, Application, Bibliography, Veroffentlichungen des Geobotanischen Institutes der ETH 1, Stiftung Rubel, Zurich. Pp.638.

Leng RA., Stambolie JH., Bell R. 1995. Duckweed - a potential high-protein feed resource for domestic animals and fish Livestock Research for Rural Development 7.

Maciejewska-Potapczykowa W., Konopska L., Narzymska E. 1970. Proteins in duckweed (Lemna minor L.). ActaSoc. Bot. Pol. 39: 251-255.

Mkandawire M., Dudel E.G. 2007. Are Lemna spp. Effective Phytoremediation Agents? GlobalSciencebooks: Bioremediation,
BiodiversityandBioavailability. 1(1), 56-71.

Mkandawire M., Dudel EG. 2005. Accumulation of arsenic in Lemna gibba L. (duckweed) in tailing waters of two abandoned uranium mines in Saxony, Germany. Science of the total Environment. 336:81-89.

Olorunfemi T.O.S., Aderibigbe F.M., Alese B.K., Fasakin E.A. 2006. Utilization of duckweed (Lemna paucicostata) in least cost feed formulation for broiler starter: A linear programming analysis. Inf. Technol. J. 5:166-171.

Radić S., D. Stipaničev P., Cvjetko M., MarijanovićRajčić S., Širac B., Pevalek-Kozlina., Pavlica M. 2011. Duckweed Lemna minor as a tool for testing toxicity and genotoxicity of surface waters. Ecotoxicol. Environ. Saf. 74:182-187.

Rojas O.J., Liu Y., H.H.Stein 2014. Concentration of metabolizable energy and digestibility of energy, phosphorus, and amino acids in lemna protein concentrate fed to growing pigs. J. Anim. Sci. 92: 5222-5229.

RusoffL.L., Blakney E.W., Culley D.D. 1980. Duckweeds (Lemnacae Family): A Potential Source of Protein and Amino Acids. J. Agric. Food Chem. 28:84850.

Scoups R. Methods cleaning proteins. Moscow. 1985. Pp.341-342c.

Steven A., Cohen Daviel J. Amino acid analysis utilizing phenylisothiocyanata derivatives. J. Analytical Biochemistry -1988. - V. 17. - № 1. -P. 1-16.

\section{How to cite this article:}

Mirzaeva, D.A., K.S. Maksumkhodjaeva, N.A. Khujamshukurov, Sh.Q. Gazieva, X.O. Abdullaev, Sh.X. Iskhakova and Kuchkarova, D.Kh. 2020. Nutritional Value of Lemnaceae Macrophytes. Int.J.Curr.Microbiol.App.Sci. 9(04): 3233-3242. doi: https://doi.org/10.20546/ijcmas.2020.904.376 